Soils and palaeo-climate based evidence for irrigation requirements in Norse Greenland

W. Paul Adderley, Ian A. Simpson

School of Biological and Environmental Sciences, University of Stirling, Stirling FK9 4LA, Scotland, UK

E-mail address: w.p.adderley@stir.ac.uk (W.P. Adderley).

Journal of Archaeological Science 33 (2006) pages: 1666 - 1679

http://dx.doi.org/10.1016/j.jas.2006.02.014 


\title{
Soils and palaeo-climate based evidence for irrigation requirements in Norse Greenland
}

\author{
W. Paul Adderley, Ian A. Simpson
}

School of Biological and Environmental Sciences, University of Stirling, Stirling FK9 4LA, Scotland, UK

\section{Abstract}

Establishing and sustaining agricultural production was a key factor in the success of Norse settlements during the landnám colonisation across the North Atlantic. In light of the occurrence of channel features in several abandoned home-field areas of the Norse Eastern Settlement of Greenland, and the irrigation requirements of presentday Greenlandic sheep-farmers questions are raised: was irrigation used by the Norse settlers of Greenland on their home-field areas? and, if so, how frequently? Modelling of soil chemical, physical and soil-water hydraulic properties integrated with contemporary highresolution climatic data demonstrate a frequent requirement for irrigation. Soil moisture deficits are related to the duration and intensity of winter temperature. Using the winter Dye 3 ice core $\delta^{18} \mathrm{O}$ record as a climatic proxy, the frequency of moisture deficits, based on comparing mean winter temperatures, indicates that there was a frequent irrigation requirement to maintain home-field productivity, increasing throughout the period of settlement until the 14th Century.

Keywords: Brattahlíð; Landnám; Home-field; Guelph Permeameter

\section{Introduction}

Norse expansion across the North Atlantic region during the 9th and 10th Centuries AD was based on the establishment of agricultural settlements. A key determinant of the success of settlements in the Faroe Islands, Iceland and Greenland was, therefore, land management to establish and maintain agricultural production to support the population of the settlement. In Greenland, the Norse colonies were founded in $A D$ 985 by Eirík porvaldsson - Erik the Red - after earlier exploration from AD 982. Many discussions on the sustainability of the Norse settlements in Greenland have examined the collapse or forced abandonment in the late 15 th or early 16 th Centuries and have focussed on the deterioration of climate 
$[6,7,9]$ and consequential societal and environmental impacts.

It has been argued that the development of hierarchical societies underpinned by control of access to fodder resources may have helped precipitate the Norse decline through overly conservative resource management $[3,44]$. Similarly, overgrazing by sheep and goats leading to soil erosion has been suggested as a factor in the Norse collapse $[27,34]$; the dental wear of sheep and goat teeth, attributed to the ingestion of eroded soil, suggests that this may have been a factor throughout the whole of the Norse settlement period [42].

In contrast, away from these discussions of crises, the influence of land management practices relative to and in response to climatic factors for the sustainability of the Norse farming system during the early period of Norse settlement in Greenland has not been considered in detail [43]. The influence of climate on food production is an obvious and major factor in the sustainability of early-Norse settlements emphasised by contemporary measurement of plant productivity suggesting year-to-year fluctuations of up to $20 \%$ in biomass production for this region [28]. In common with Norse settlement sites in the Faroe Islands and in Iceland $[1,4,45]$ and given the fluctuations seen in present-day agricultural yield, it is clear that an understanding of the management of early agricultural activity is crucial to developing an insight to the long-term sustainability of the Norse settlement in Greenland.

The rearing of grazing livestock including cattle, sheep, goats and geese is an obvious and key component of earlyNorse farming practices. Such animal husbandry is in turn dependent on the management of grassland: the extensive rangeland outfield area for summer grazing and the home-field area to produce sufficient fodder to feed livestock through winter. In a range of Norse contexts in the Faroes and Iceland $[1,57]$ it has been demonstrated that, for successful home-field production, management of nutrients through manure applications is essential to maintain fertility and, furthermore, that such manure management may help alleviate short-term, i.e. year-to-year, climatic fluctuations. In each of these contexts, the availability of water for plant growth has not been found limiting, yet present-day Greenlandic farmers periodically require irrigation for grass production in several areas which previously formed part of the Norse Østerbygden, or, Eastern Settlement. With previous surveys of farms in the Eastern 
Settlement interpreting relict channels seen in field systems as irrigation ditches $[25,40]$ and comparison of this field evidence being made with other locales [5], two obvious questions are raised: (i) Was irrigation required by the Norse settlers of Greenland to maintain grass production on the home-field? and (ii) If so, was irrigation of the home-field required every year, or only infrequently?

While archaeological studies of irrigation systems in temperate and tropical contexts are relatively common, there are no environmental studies of past irrigation systems in subarctic regions. Furthermore, the possible Greenlandic use of irrigation as an auxiliary supply of water to grassland, rather than to an alternative crop, negates the possibility of using methods successfully used elsewhere to identify irrigation sources such as use of diatom markers [64]. Understanding the weed ecology can reveal past irrigation of cereal crops [12]; functional analysis of the grassland flora has been successfully used to examine hay crops [32], but the effects of past irrigation could be confounded with several other factors identified as affecting site productivity. Regardless of the period and location, the requirement for field irrigation at any particular site is dependent upon a number of factors: these are the water inputs through precipitation and ground-water movement, water drainage from the site, transpiration by plants and evaporation from the vegetation and soil surfaces.

Through considering the requirements for hay crop production in the Eastern Settlement in Greenland, this paper describes how through linking contemporary climate measurements and paleoclimatic regimes with measurement of relict soil properties, an assessment of irrigation requirements for grass production by the Norse settlers can be made. This is addressed in three steps: first, by examining the physical properties of the relict soils an understanding of the intrinsic hydraulic properties of the soils in the home-field areas used by the Norse settlers can be found. Second, by investigating detailed modern climate data, periods of plant stress - where irrigation would be beneficial for sustained production - can be identified by combining the climatic data with the soil data. Third, comparisons between modern-day climate data and paleoclimatic reconstructions, allow possible markers of an irrigation requirement in the proxy record to be identified, thereby allowing assessment of the frequency and intensity for 
which irrigation, if any, was required by the Norse settlers in Greenland. The synthesis of these three sets of data using a model based approach allows the question of irrigation of grassland as an early-Norse land management practice to be addressed.

\section{Study sites}

Two study sites in the area of the Norse Eastern Settlement, towards the head of Tunindliarfik Fjord (Erik's Fjord) were examined (Fig. 1). The first site is at the present-day settlement of Qassiarsuk (Figs. 1 and 2). Although there is occasional speculation about other locations [24], Qassiarsuk is commonly considered to be the location of Brattahlíd, the site of first settlement by Eirík porvaldsson which later developed into a more extensive medieval Norse settlement. The second site is at Tasersuaq, between the Tunindliarfik and Sermilik Fjords (Fig. 1). This site has no present-day settlement but Norse ruins are visible (Fig. 3). The geology of the area is mixed: biotite-rich gneiss underlies the north of the Quassiarsuk (Brattahlíð) site with sandstones underlying the southern portion [22]. The Tasersuaq site also lies on mixed geology with visible outcrops of sandstone and biotite-rich granite. The soils in the region have not been surveyed in detail; however, a chemical study [56] of five profiles from a variety of sites in the Eastern Settlement areas concluded that there were no obvious nutrient deficiencies for subsistence production on these soils. Another soils study [33] reported podzol-development in several locations, with the pedological development of such soils suggested as indicating long-term soil development extending through the Holocene. The other soil factor is the potential loss of soil through erosion, with recent and historical overgrazing problems suggested as a factor in the abandonment of the Norse colony $[33,34]$. Much of the past paleo-environmental research in the area has focussed on the pollen and macrofossil record [18e21]. In common with Iceland and the Faroe Islands, the major change in the pollen record at landnám is the sequential reduction in tree and shrub species (Salix sp., Betula sp.) and a rise in grasses (Poaceae). With the exception of a single pollen grain of barley type (Hordeum) [19] there is no evidence of attempts at cereal cultivation during the Norse settlement. 
The extensive Norse and Inuit ruins at Qassiarsuk (Fig. 2) have been subject to several archaeological surveys [8,25, $40,48,55]$. Most excavations have focussed heavily on the early-Norse Church and nearby Norse ruins $[40,46,48]$ and the midden area is presently being investigated (Paulsen, personal communication). The notation of surveyed ruins in Greenland has two systems: the notation of Brunn ([8] et seq.) which considered only Norse ruins, and a more recent

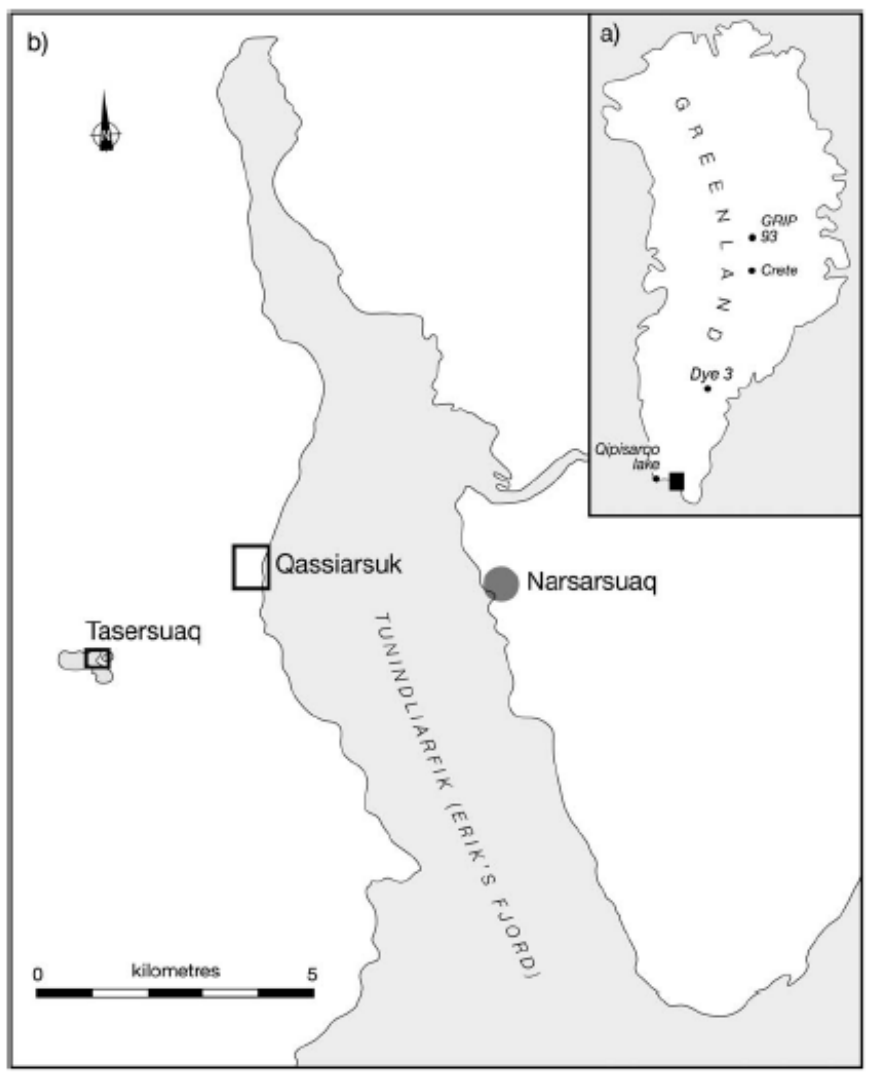

Fig. 1. Site locations: (a) paleo-climate data sources and (b) field-work locations within the former Norse Østerbygden (Eastern Settlement) of Greenland.

numbering scheme including both Norse and Inuit ruins [7]. At Qassiarsuk the ruins are designated as two separate sections in both notation systems, the northern section, including the Norse Church, Ruin Group 539 (Brattahlíz; Settlement $\varnothing$ 29a) and the southern section - Ruin Group 540 (Brattahlíd; Settlement $\varnothing 29$ ). The site topography is characterised by an east-facing aspect, with a terrace, possibly a relict raised beach, to the west of the present-day infield areas (Fig. 2). Present-day activities at Qassiarsuk are centred on sheepfarming and limited tourism, with soil disturbance limited to 
disk-harrowing of the soil surface during the reseeding of grassland. The infield area has been expanded in recent years with land taken in hand through fencing and pasture improvements such as the removal of boulders; therefore, Nørlund and Stenbergers's [48] survey has been used as a basis for Fig. 2. A distinct relict channel positioned to draw water from the small river running through the settlement, is clearly visible (Fig. 2) and past surveys have considered that this was created by the Norse settlers for home-field irrigation.

The ruin group at Tasersuaq (Ruin Group 542; Settlement $\varnothing 31$ ) has been previously surveyed by Brunn [8] and by Guldager et al. [25] (Fig. 3). Presently, this site lies within an extensive area of rough grazing and is therefore subject to little soil disturbance. An area of permanent pasture lies adjacent to the ruins; given the minimal disturbance of the whole area, this is likely to have been the maximum extent of home-field for the Norse settlement (Fig. 3). The Tasersuaq site lies between two lakes of different topographic elevations. Distinct relict channels, emanating from a single take-off point on the uppermost lake, are visible on the land surface. From field survey, these have been previously interpreted as irrigation ditches [25].

\section{Site climate}

The climate of Southern Greenland is dominated by seasonal temperature extremes between land and sea. Away from the ice cap, in winter the sea is relatively warm and in summer relatively cold, this leads to land breezes in winter and sea breezes in summer. A characteristic of the region are katabatic winds emanating from the ice cap. These drying winds can reach gale force and can persist for many days [11]. 


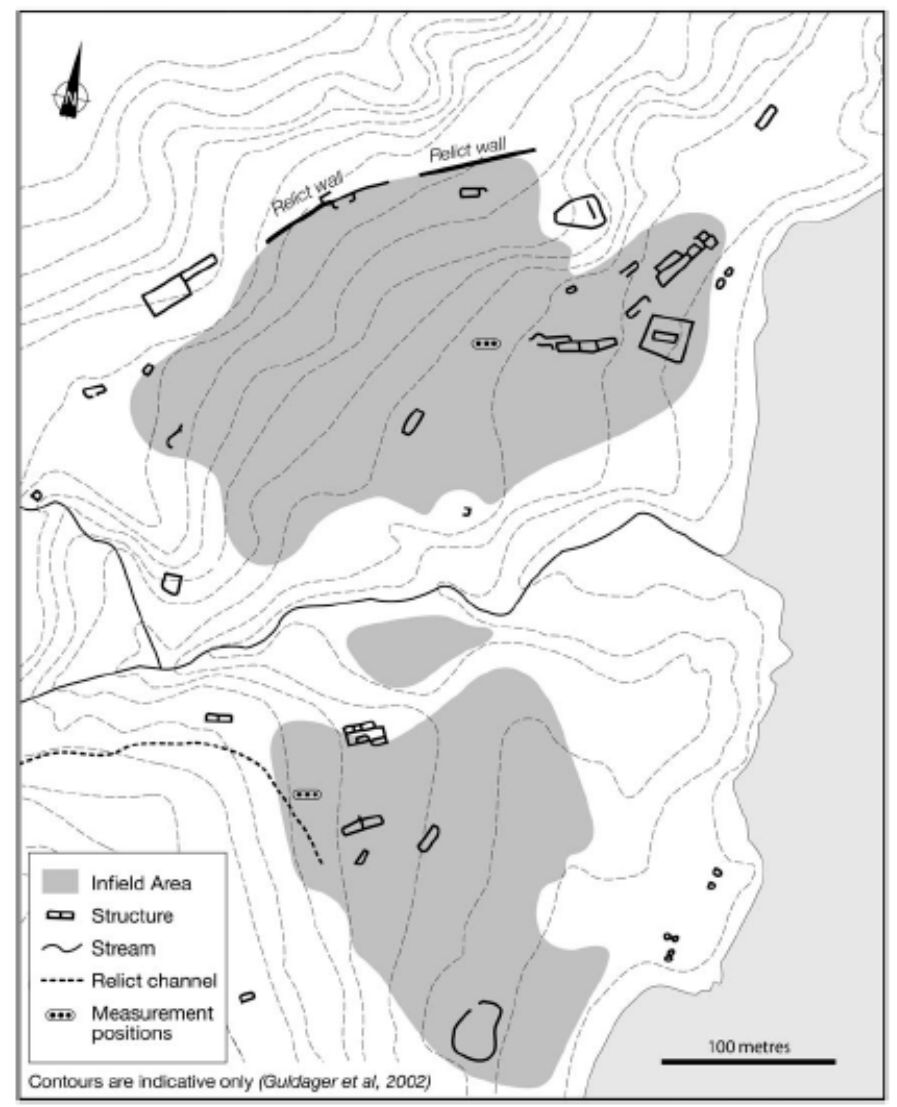

Fig. 2. Map of Qassiarsuk, site of the medieval Norse settlement Brattahlíð, showing locations of Norse ruin groups, Norse home-field area, relict channel and the permeameter measurement positions (adapted after $[25,40,48]$ ).

Present-day climatic observations are made at 21 weather stations in Greenland with the nearest and most representative for both the study sites located at Narsarsuaq airfield, originally known as Bluie West 1 during World War II. (WMO station no. 34270;61 $10^{\prime} \mathrm{N} ; 4^{\circ} 25^{\prime} \mathrm{W} ; 24 \mathrm{~m}$ above sea level (asl); Fig. 1). Continuous temperature and precipitation data have been collected at this meteorological station since 1958, with sunshine measurements taken since 1980. Standard temperature normals for 1961-1990 are shown in Table 1 [11]. To allow for high-resolution analyses data have been obtained and collated on a daily basis for the period 19802003 from the Narsarsuaq weather station (Fig. 4aed). Comparing years, the maximum temperatures seen in summer vary little whereas pronounced differences are seen in the winter temperatures (Fig. 4a). Precipitation inputs arise from regular small events rather than as erratic extreme events (Fig. 4b) but shows pronounced variations in the total input (Fig. 4c). This shows an inverse relationship with magnitude of the wind's 
speed (Fig. 4d). The two study sites are in close proximity to each other and lie towards the head of the fjord. These sites experience more continental climatic conditions than the seaward end of the fjord; this is highlighted in the length of summer period with a mean period of 115 days continuous frost-free at Narsarsuaq compared with 68 days at Qaqortoq $\left(60^{\circ} 43^{\prime} \mathrm{N} ; 46^{\circ} 03^{\prime} \mathrm{W}\right)$ [11].

Palaeo-climatic studies of Southern Greenland considering the Norse landnám period are primarily based on the use of ice core proxy information for, unlike Iceland, there is little or no surviving climate history sources from the early-Norse period [49]. For later periods, literature sources indicate that there were prolonged cold periods, with ice restricting shipping throughout the 14th Century [50,51]. Palaeo-temperature reconstructions can be made from ice cores either from direct measurement of temperature at a sequence of depths in the ice core borehole or through considering isotopic ratios. Relative differences in air temperatures can be inferred from analyses of the stable oxygen isotope records in incremental ice layers. The ice's stable isotope ratio relative to that of Standard Mean Ocean Water $\left({ }^{18} \mathrm{O} /{ }^{16} \mathrm{O}\right.$ - commonly expressed as $\left.\delta^{18} \mathrm{O}\right)$, reflects the temperature of the cloud vapour, and in turn the

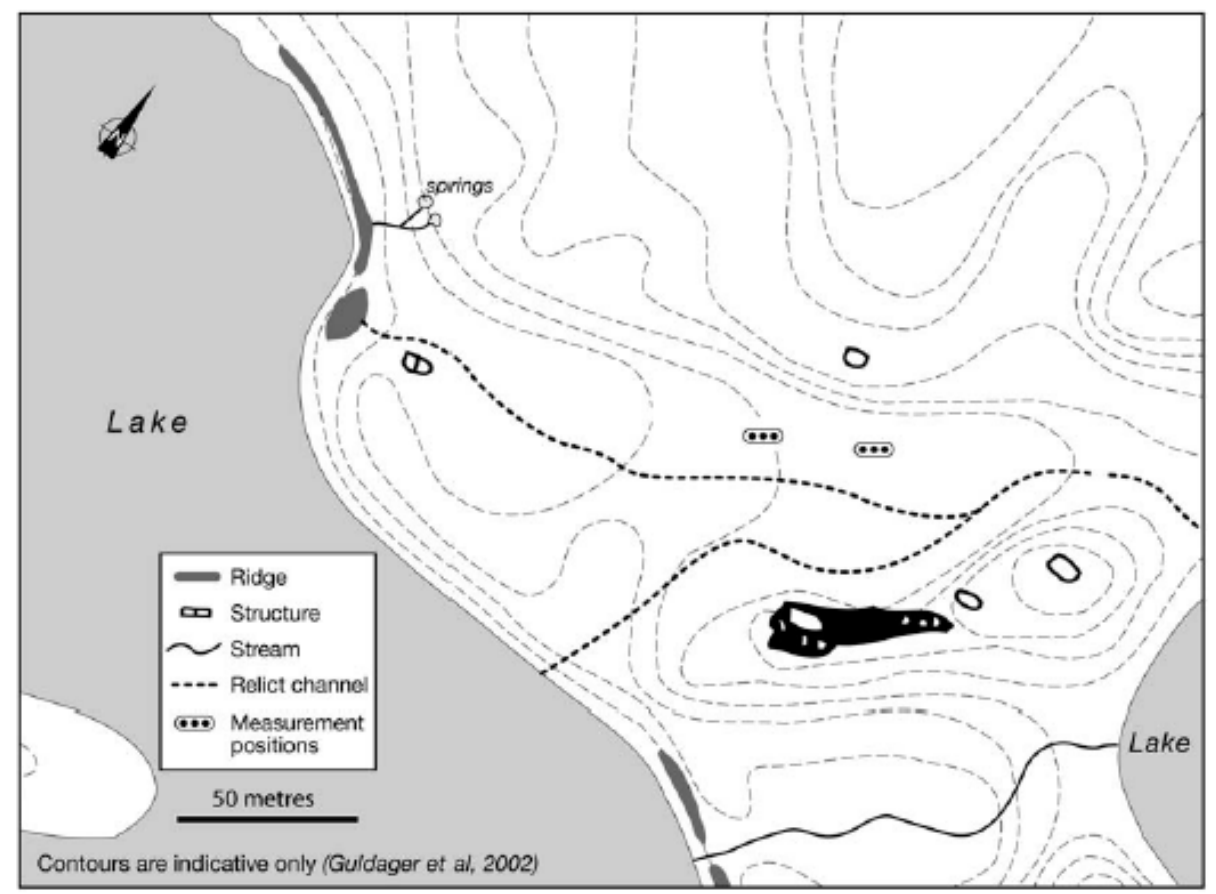

Fig. 3. Map of Tasersuaq, Southern Greenland showing positions of the Norse ruin group, relict field channels, and permeameter sampling positions (after [25]). 
air temperature, at the time of formation of the snow which formed the accumulating ice [14]. These data can be seasonally resolved and show good correlations with contemporary instrumental records $[6,36,60]$. However, since ice accumulation occurs only with precipitation there is an inherent bias in $\delta^{18} \mathrm{O}$ records with the winter record the most robust seasonal proxy $[38,66]$. For this comparison, winter $\delta^{18} \mathrm{O}$ data have been used following an established protocol [66] which takes a fixed period of accumulation and can be considered a proxy of the severity of each winter, i.e. mean winter temperature from December to March inclusive.

The Dye 3 ice coring site $\left(65^{\circ} 11^{\prime} \mathrm{N} ; 43^{\circ} 50^{\prime} \mathrm{W} ; 2480 \mathrm{~m}\right.$ asl) is the closest to the Quassiarsuk and Tassersuaq sites. Data from the ice cap summit GRIP $93\left(72^{\circ} 35^{\prime} \mathrm{N}, 37^{\circ} 38^{\prime}\right.$ W; $3230 \mathrm{~m}$ asl) and Crete $\left(71^{\circ} 07^{\prime} \mathrm{N}, 37^{\circ} 19^{\prime} \mathrm{W} ; 3172 \mathrm{~m}\right.$ asl) ice cores (Fig. 1) are used for comparison. The directly measured ice core temperatures from the Dye 379 core and corresponding measurements from the GRIP core are shown in Fig. 5a, b [13] and cover the landnám period. These data have a relatively coarse temporal resolution, but allow longterm trends in climatic warming and cooling to be considered. The winter $\delta^{18} \mathrm{O}$ measurements for the Dye 379 and Crete ice cores from AD 900 to 1970 are shown in Fig. 5c, d (Vinther, personal communication) and allow relative year-to-year comparisons of the winter temperature. In both the direct borehole temperatures and in the winter $\delta^{18} \mathrm{O}$ data there are good agreement between the trends seen in the Dye 3 and GRIP 93 and Crete data sets and with instrumental records. For the highresolution ice core data, correlations versus December-March Southern Greenland temperatures as defined by Vinther et al. [66] are $r=0.59$ for Dye 379 and $r=0.45$ for Crete. The lower altitude and more southerly position of the Dye 3 coring site is also seen in the warmer temperatures recorded in the proxy (i.e. greater $\delta^{18} \mathrm{O}$ value). Independent from the ice core data, analyses of biogenic silica concentrations, a proxy for past air temperature, from lake sediment samples taken at Qipisarqo (61 $01^{\prime} \mathrm{N}, 47^{\circ} 45^{\prime} \mathrm{W}$; $7 \mathrm{~m}$ asl; Fig. 1), a coastal site $120 \mathrm{~km}$ south-west of Qassiarsuk (Brattahlíd), show close correspondence with the Dye 3 ice core data [39] further confirming the overall climatic trend. 


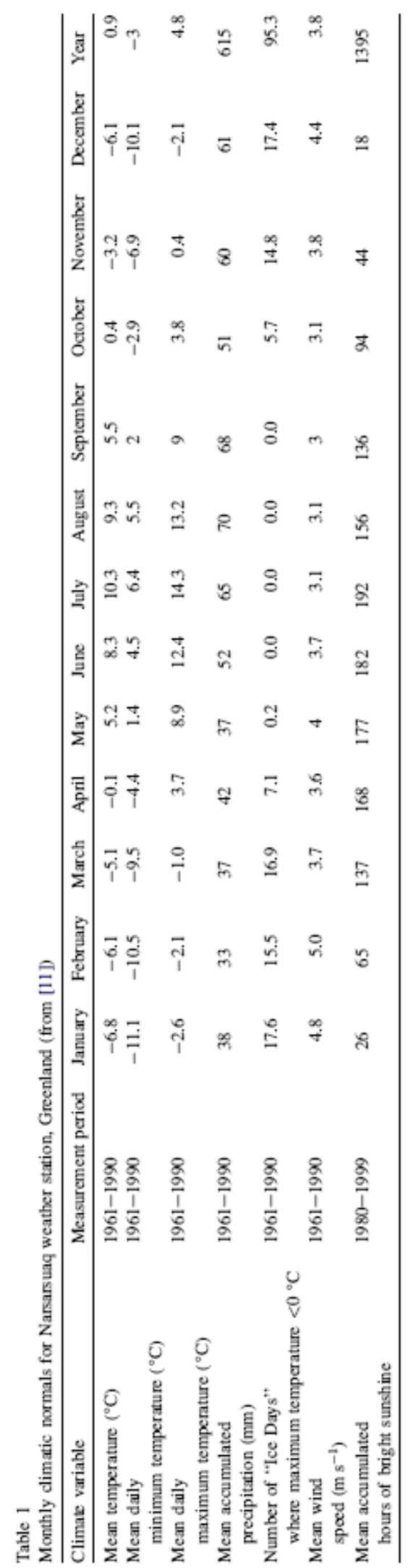

4. Field methods

\subsection{Soil sampling and analysis}

Physical properties of the soils from the two field sites were measured using a mixture of laboratory measurements and in situ field observations and measurements. Two profiles were exposed at each of the Norse home-field areas at Quassiarsuk (Brattahlíð) (Fig. 2) and at the Tasersuaq (Fig. 3). Following field survey, profiles positions were selected in areas representative of the majority of each home-field in terms of slope and aspect. These positions were further limited in order not to disturb ruin groups and their surrounding buffer zones. At Qassiarsuk, modern disturbances such as farm tracks were avoided. Field description was based on Hodgson [31]. Soil samples were collected from selected depths. Bulk density was measured using fixed-volume samples. The particle size distribution was measured following wet-oxidation of organic matter, using a Coulter LS200 instrument. Soil organic matter, included in the calculation of soil hydraulic properties through pedotransfer functions [52], was measured on further subsamples by the WalkleyeBlack method [47].

4.2. In situ soil permeameter analysis

To assess the transfer of water through the Norse home-field soils a set of in situ measurements of fieldsaturated hydraulic conductivity $\left(\mathrm{K}_{\mathrm{fs}}\right)$ were obtained. These measurements 
were made using a Guelph Permeameter, a constanthead in-hole permeameter apparatus which is based on the principle of a Mariotte bottle (Fig. 6). The apparatus is used to measure the steady-state recharge into unsaturated soil required to maintain a constant depth, or head, of water above the bottom of a cylindrical well-hole [53]. For use in Greenland, the apparatus was modified to provide greater stability on uneven ground and during strong wind gusts. Locations for sampling were selected on the basis of the presentday land surface thereby avoiding interference by modern agricultural machinery, and on the position of the home-field area. Three independent measurements at $5 \mathrm{~m}$ spacing were made at each location marked on Figs. 2 and 3.

A standardised measurement protocol was followed [41,59]. A wellhole $20 \mathrm{~cm}$ deep was augered at each sample location. The well-hole was cleaned by brush to remove any smearing; other suggested wellhole preparation procedures [41] were tested and found not to be necessary. A set of measurements was made at 1 min intervals for 15 min with a $5 \mathrm{~cm}$ constant head height. At Tasersuaq, the wellholes were then deepened to $40 \mathrm{~cm}$ and the procedure repeated. All measurements were made without interference from any precipitation inputs with dry weather before and during measurements.

\subsection{Permeameter data treatment}

The data from the permeameter measurements at each sample/ sample depth combination were analysed by two methods calculated using a single head. This allows both intra-site comparisons and comparisons with data from previous studies. The first method adopted is based on the Laplace analysis of flow and only considers the saturated component of such water movement [16]. This method tends to overestimate $\mathrm{K}_{\mathrm{fs}}$. The second data treatment is the so-called Richards analysis. This requires an estimation of soil capillarity deduced from the soil's textural and structural properties. The method then uses Richards analysis of flow to calculate $\mathrm{K}_{\mathrm{fs}}$ [54]. This method has the disadvantage of requiring an estimated variable, but the advantage over the Laplace analysis of considering both saturated and unsaturated components. In both instances these data tend to a logarithmic distribution, so to summarise the results a geometric rather than an arithmetic mean has been calculated, along with the range and standard deviation. 


\section{Soil-water-plant balance modelling}

To consider the need for water management at the two sites, the contemporary climate measurements have been used to consider the effect of water management on grass growth. Changes in water inputs and losses due to both climate and plant growth factors have effects on the depth of the water table and the water content of the soil in the plant-root zone. If there is a prolonged lack of water in the plant-root zone, then plant growth will suffer. Conversely, if there is too much water in the plant-root zone, then the soil may become anoxic,
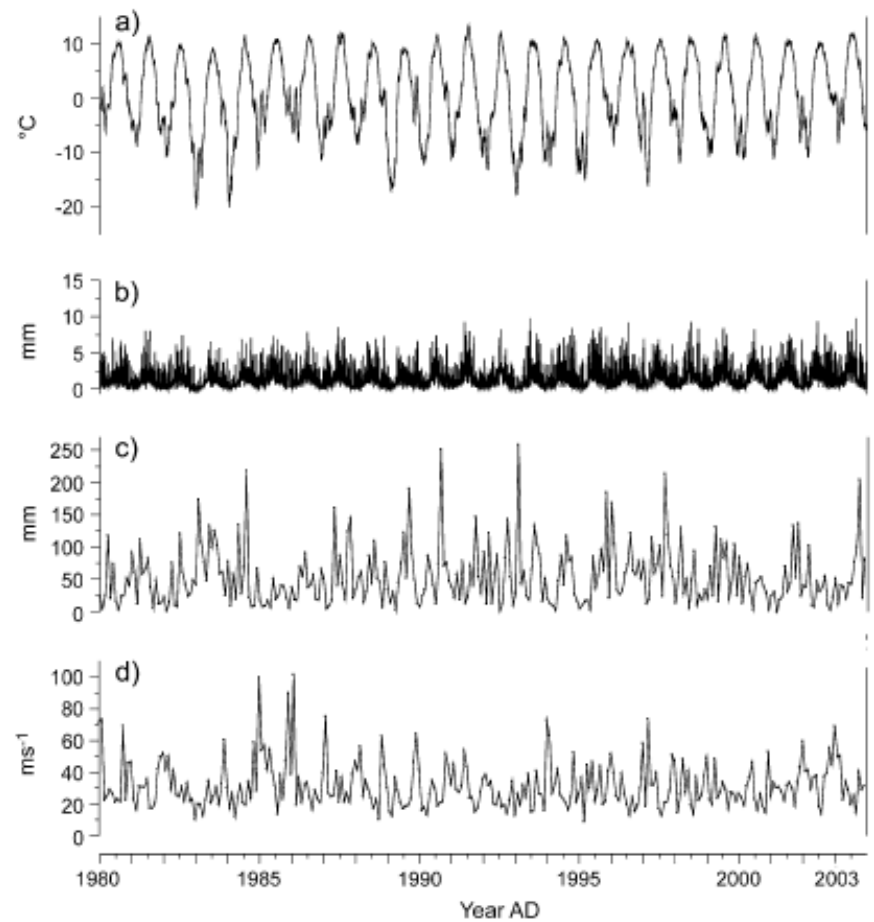

Fig. 4. Contemporary climate data at Narsarsuaq (a) 30-day moving average (b) daily precipitation (c) 30-day moving mean precipitation (d) daily vector mean wind speed.

again detrimental to plant growth. Using a field-level model of soil-water-plant interactions WaSim $[29,30]$ the soilewater balance has been calculated on a daily basis for the period 1980-2003. The WaSim model considers water input from precipitation, water movement through the soil, and removal of water through site drainage and evapotranspiration (Fig. 7).

Evapotranspiration is a combination of: (i) water directly evaporating from soil and plant surfaces, and (ii) water transpired 
by plants. It is a key variable in the plant-soil-water balance; at the start of the growing season, direct evaporation from soil will be the major component of the evapotranspiration value, whereas the contribution from plant transpiration will increase as the plants grow. Evapotranspiration values were calculated using the PenmaneMonteith equation [2] using a set of site parameters (ground surface cover, site latitude, albedo and soil heat flux) and four key climatic variables (wind speed, solar radiation, relative humidity and air temperature). Surface runoff of precipitation is included in the model and has been calculated using past measurements on temperate North American permanent pastures [58]. The model is particularly sensitive to the drainage characteristics of the site, especially given the limited depth of these soils. However, if the hydraulic conductivity of the parent material underlying the soil parent material is much greater (e.g. an order of magnitude greater) than the soil itself, then the model's boundary conditions can be assumed to be limited to the depth of the soil profile. Reported hydraulic conductivities for a variety of geological materials sampled at multiple locations [61] have therefore been used as a comparator.

Soil properties are incorporated into the model in order to calculate the redistribution of water in the profile. These include the hydraulic conductivity of the soil as measured by the Guelph Permeameter using the Richards data analysis method, with other soil-water retention properties calculated using validated pedotransfer formulae $[23,52]$. Plant growth and growing season parameters were specified based on contemporary observations at Narsarsuaq [63]. Using the measurements from $20 \mathrm{~cm}$ soil depth at Qassiarsuk, and for the $20 \mathrm{~cm}$ and $40 \mathrm{~cm}$ soil-depths at Tasersuaq, three model runs for the period 1980-2003 have been calculated. The model assumes that these soil properties are uniform throughout the soil profile, thereby allowing a depth-independent comparison.

\section{Results and discussion}

\subsection{Soil measurements}

The results of the physical soil measurements and permeameter measurements of the soils are shown in Table 2. Both the physical and water permeability measurements reveal clear differences 
a)

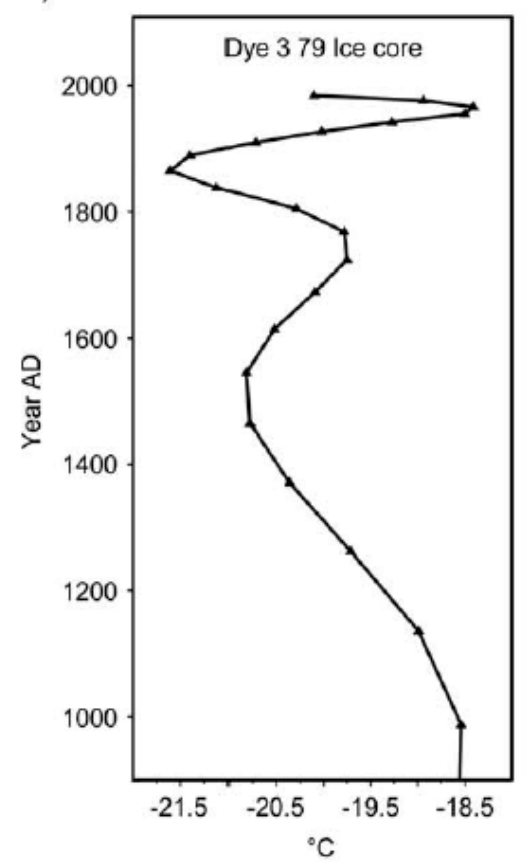

c)

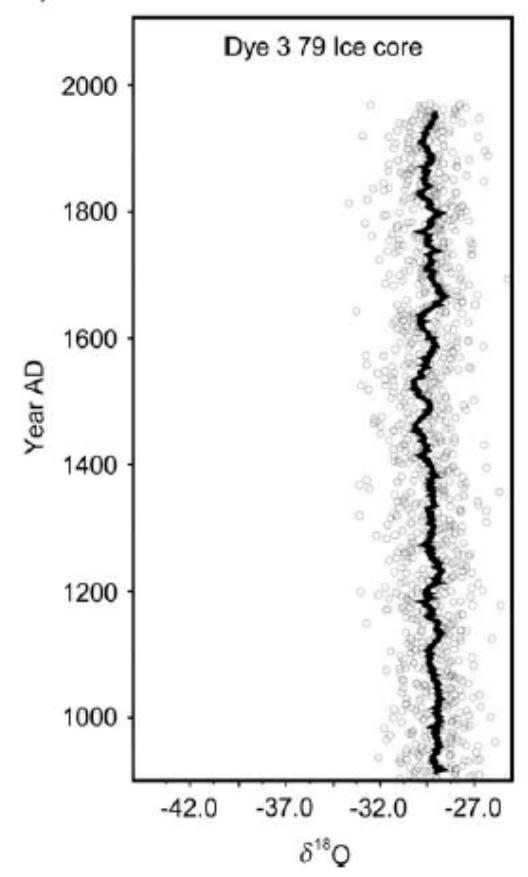

b)

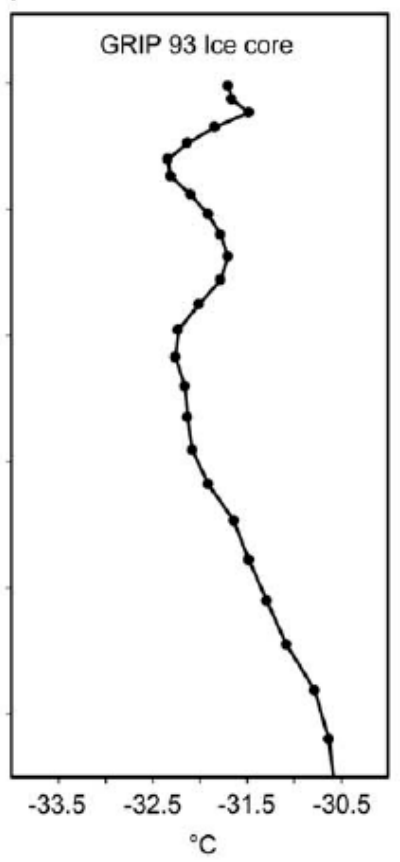

d)

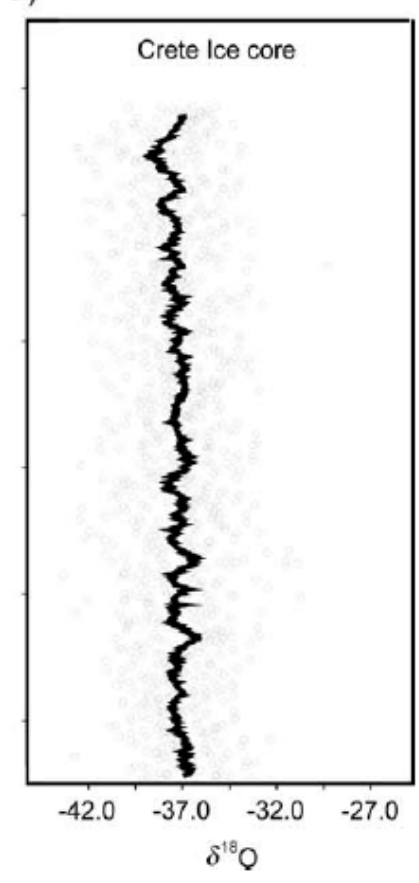

Fig. 5. Greenlandic ice core data: (a) direct temperature measurement of the Dye 3 ice core [13]; (b) direct temperature measurement of the GRIP ice core [13]; (c) winter $\delta^{18} \mathrm{O}$ profile from Dye 379 ice core (Vinther, personal communication) with 30 year moving average plotted in boldface; (d) winter $\delta^{18} \mathrm{O}$ profile from Crete ice core (Vinther, personal communication) with 30 year moving average plotted in boldface. Winters are defined as specified in Vinther et al. [66]. Diffusion corrections applied to the Crete ice core data follow the methodology of Johnsen et al. [35]. 


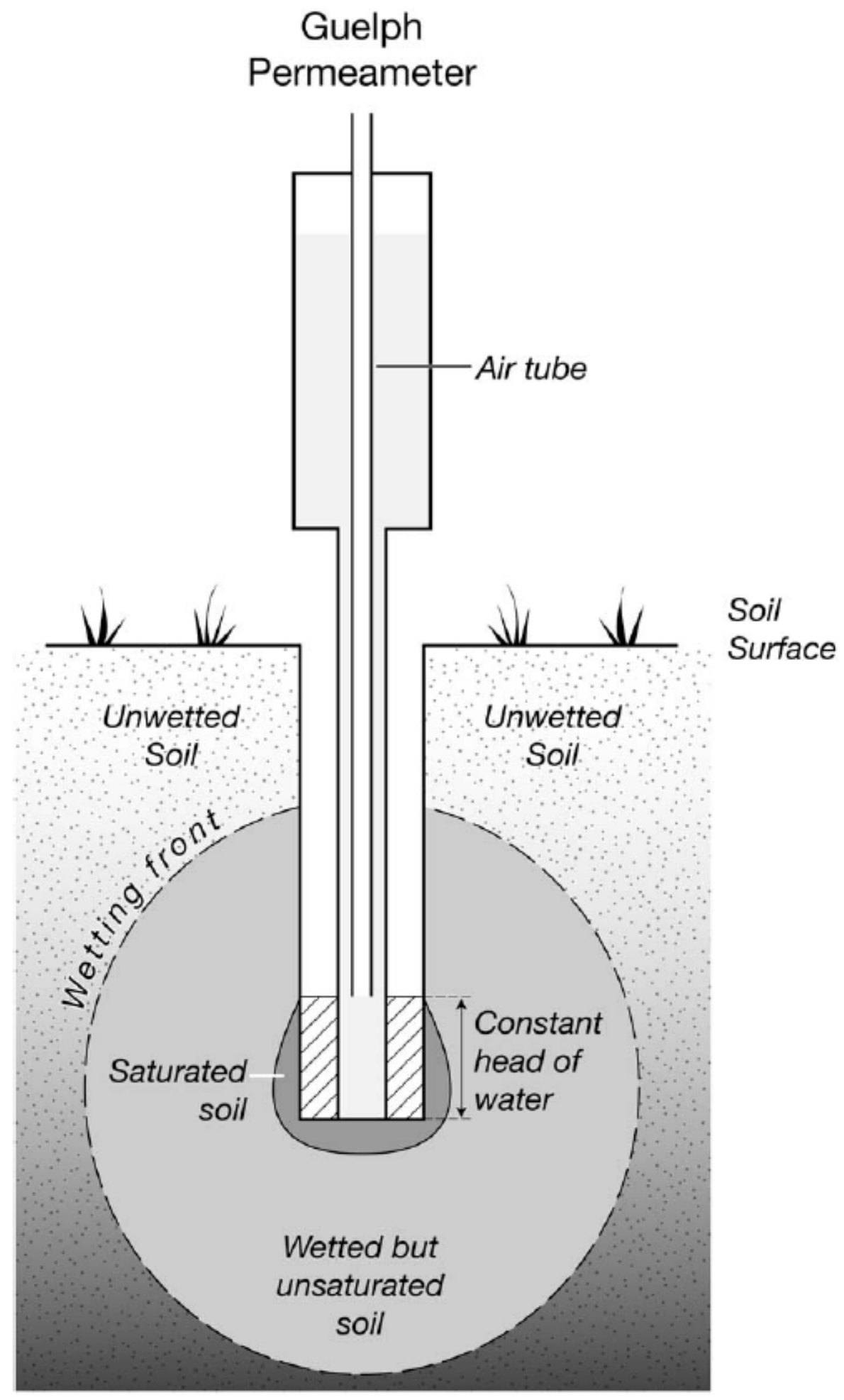

Fig. 6. Schematic drawing of the Guelph Permeameter apparatus design. Based on the Mariotte bottle principle, with the top sealed a constant head of water in the augered well-hole is maintained. Raising the height of the air tube relative to the outlet will increase the height of the constant head. 
between the two sites with the Tasersuaq site characterised by greater mean $\mathrm{K}_{\mathrm{fs}}$ values and by stonier soils than those found at Qassiarsuk. The results of the Guelph Permeameter measurements show large ranges of values and standard deviations at each site (Table 2). This variability is undoubtedly due to soil heterogeneity including the relative stoniness of each profile. It can also be ascribed in part to the shallow depth of the soils. The high values relative to the mean are likely to have occurred in circumstances where water flow during the measurement partially occurred in large voids in the soil parent material, a phenomenon frequently called pipeflow, rather than solely into the soil matrix. At Tasersuaq, the mean $\mathrm{K}_{\mathrm{fs}}$ values are greater at the $40 \mathrm{~cm}$ depth than at $20 \mathrm{~cm}$ and correspond to the coarser soil material.

The permeameter data show the same trends regardless of the data treatment applied for both the mean and range values between sample sites and depths. This suggests that regardless of any differences in the flow characteristics in the soil (saturated only vs. unsaturated and saturated) that these differences are consistent. The mean $\mathrm{K}_{\mathrm{fs}}$ values for the $20 \mathrm{~cm}$ depth samples at both sites are very similar to those found in upland topsoils in Scotland [41]. However, the mean $\mathrm{K}_{\mathrm{fs}}$ values at the $40 \mathrm{~cm}$ depth sampling at Tasersuaq are significantly higher than those previously reported for "subsoil" and for parent materials [41]. It is therefore likely that the observed conductivity of the deeper horizon is influenced by the porosity and connectivity of pores in the underlying glaciofluvial deposits. 


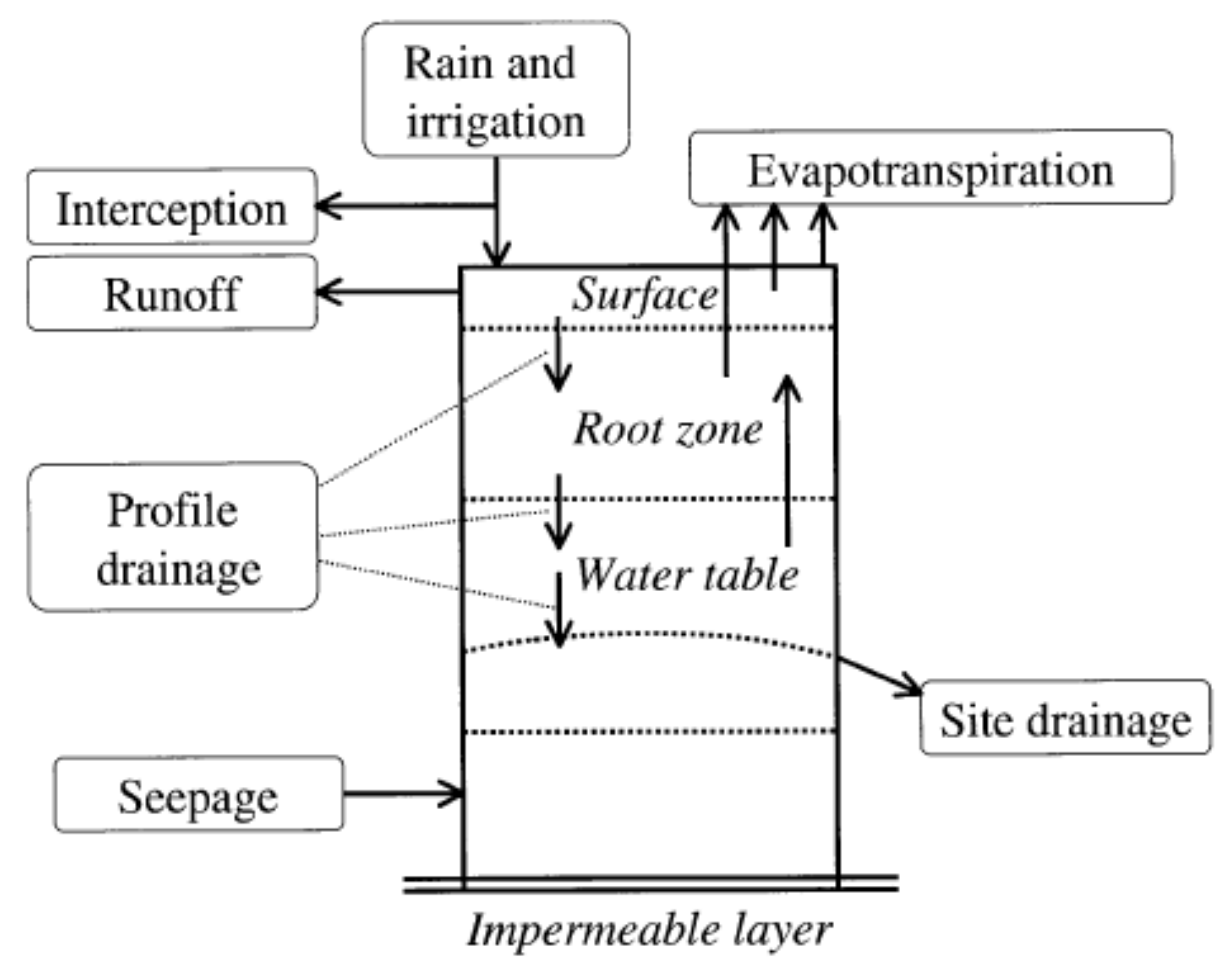

Fig. 7. Field-scale soil-water-plant interactions modelled by WaSim [30].

6.2. Modelled irrigation requirement from contemporary climate measurements

The modelled soil-plant-water balance shows a water deficit in the plant-root zone occurring each year of values up to c.70 $\mathrm{mm}$ and for varying periods (Fig. 8a-c). Differences between both Qassiarsuk and Tasersuaq at $20 \mathrm{~cm}$ and between $20 \mathrm{~cm}$ and $40 \mathrm{~cm}$ depths at Tasersuaq are revealed. Since the climatic data modelled are consistent for each location, these differences represent the effect of inherent soil properties including organic matter content and particle size distribution (Table 2). Since grassland is not a determinate crop (i.e. not grown for mature seed), the fact that there are water deficits each year does not necessarily indicate significant water stress such that there is an impact on crop yield. It is indeed the combination of the magnitude of the water deficit and the period that the deficit persists that is important. Both the establishment of plant growth after dormancy and the ultimate fodder production of the grassland each year will be dependent upon this combined factor. Using the twin criteria of a moisture deficit threshold of $15 \mathrm{~mm}$ and persistence of these conditions 
for longer than 23 days (i.e. $20 \%$ of available growing season), periods of significant plant water stress are highlighted $([10,29,67]$; Fig. 8a-c). The effect of the deficit on the grass will occur in two stages, a reduction in plant transpiration followed by a reduction in plant growth.

From the 24-year period considered, five years (1985, 1991, $1995,2001,2003$ ) show such pronounced deficits that would warrant irrigation inputs to maintain plant growth at both sites considered. These moisture deficit periods follow relatively warm winters (Fig. 8d) and/or where wind speeds are generally higher (Fig. 4d). These two factors are seen confounded in the calculated evapotranspiration values (Fig. 8e). The effect of individual prolonged gale force storms with a dry katabatic wind emanating from over the ice sheet is mixed; these events appear to be significant in some years, e.g. 1985 (Fig. 8f) but are not consistently found in years with moisture deficits. It is therefore year-to-year variation in the general prevailing weather conditions rather than localised extreme events that appears significant in determining the soil moisture deficit and the consequent need to irrigate grassland.

The major limitations and sensitivities of the modelling analysis concern the quantification of three model variables. First is the problem of specifying plant growth parameters for a permanent pasture crop since the dates relating to the onset of growth, to the period of anthesis (commencement of flowering) and to plant senescence will vary each year. Pronounced variations in these timings have been observed during studies of grass growth at Narsarsuaq [63]. Specifying plant growth timings, which are obviously not independent of the climatic conditions is therefore required to be typical. The limited duration of the field studies upon which these values have been taken is a major limitation. Second, the model is particularly sensitive to changes in the specification of drainage characteristics of the underlying sediment. In the two sites considered the underlying glaciofluvial deposits appear to be particularly porous; reported hydraulic conductivities for such materials are of up to $100 \mathrm{~m} \mathrm{day}^{-1}$ [61]. The assumption about the underlying drainage made in the model therefore appears valid, although complete verification would require catchment-level hydrological analyses relative to local precipitation inputs. Thirdly, the relationships between soil-water movement relative to air and soil temperatures are obvious 
issues in this climatic environment. The effects of frozen soil and the duration of snow cover are not directly modelled but are considered in the seasonal timing of the grass growth used in the model. However, since these climate factors may have a confounded effect they may have a major role on annual productivity. Obviously if the ground is frozen at the surface there will be no grass growth during these periods, but these conditions will also alter the soil moisture regime. A greater quantity of precipitation will runoff the soil surface if the soil is frozen, and since snow is a poor thermal conductor prolonged snow cover may significantly extend the period for which the ground is frozen after each winter. The modelled outputs therefore can be seen as a best-case with these factors confounding the water deficit and further reducing the period of plant growth.

A further implication of the effect of freezing and thawing on the soils at the two sites may be the effect of land-cover on the soil's pedogenic development. Comparative analyses under different land-covers in Norway have revealed marked changes in soil micromorphology and, by implication, attendant physical properties apparent after only $40 \mathrm{e} 70$ years [62]. In Greenlandic contexts, therefore, if the soils were otherwise unmodified, the effect of changes to the vegetative land-cover during the landnám settlement on soil hydraulic conductivity may have become apparent after a similar period. As yet there is no convincing micromorphological or chemical evidence of manuring practices associated with

\begin{tabular}{|c|c|c|c|}
\hline \multirow[t]{2}{*}{ Depth (cm) } & \multicolumn{2}{|l|}{ Tasersuaq } & \multirow{2}{*}{$\frac{\text { Qassiarsuk }}{20}$} \\
\hline & 20 & 40 & \\
\hline Field properties & $\begin{array}{l}7.5 \text { YR } 4 / 4 \text { to } 7.5 \text { YR } 3 / 2 \text { dark brown; } \\
\text { sandy silt loam; common large stones; } \\
\text { few fine charcoal fragments }\end{array}$ & $\begin{array}{l}7.5 \text { YR } 4 / 4 \text { dark brown; (gritty) sandy loam; } \\
\text { abundant medium and small stones }\end{array}$ & $\begin{array}{l}7.5 \mathrm{YR} 3 / 2 \text { dark brown; } \\
\text { sandy silt loam (gravel); } \\
\text { frequent/very abundant medium stones }\end{array}$ \\
\hline Organic matter $(\%)$ & 7.6 & 1.0 & 15.1 \\
\hline Bulk density $\left(\mathrm{g} \mathrm{cm}^{-3}\right)$ & 1.02 & 1.12 & 0.96 \\
\hline Sand $(\%)$ & 43.9 & 62.3 & 59.4 \\
\hline Silt (\%) & 51.0 & 32.0 & 36.3 \\
\hline Clay $(\%)$ & 5.1 & 5.7 & 4.3 \\
\hline \multicolumn{4}{|c|}{ Hydraulic conductivity $K_{\mathrm{fs}}$, Richards analysis } \\
\hline Geometric mean $(\mathrm{cm} /$ day $)$ & 26 & 70 & 15 \\
\hline Maximum (cm/day) & 354 & 510 & 147 \\
\hline Minimum (cm/day) & 9 & 16 & 3 \\
\hline Standard deviation & 119 & 172 & 46 \\
\hline \multicolumn{4}{|c|}{ Hydraulic conductivity $K_{\mathrm{fs}}$, Laplace analysis } \\
\hline Geometric mean $(\mathrm{cm} /$ day $)$ & 59 & 157 & 29 \\
\hline Maximum (cm/day) & 864 & 1210 & 371 \\
\hline Minimum (cm/day) & 17 & 43 & 7 \\
\hline Standard deviation & 260 & 357 & 113 \\
\hline
\end{tabular}


these soils in contrast to the Norse home-field management practices examined in Icelandic and Faroese contexts. These typically show evidence of manuring inputs which have a demonstrable effect in moderating year-to-year climatic changes $[1,57]$. The Norse Greenland grassland crop production at these settlements will therefore have been more sensitive to year-to-year climate changes than at other North Atlantic contexts. The likely impact on grassland plant species [26] or functional types [32] is therefore also likely to have shown contrasts between situations where consistent hay production was maintained and where year-to-year differences were experienced.

\subsection{Linkage with palaeo-climate record}

To link the contemporary data to the palaeo-climate records available, the relationships between different climate factors and soil moisture deficits have been examined. Statistical comparison of the total moisture deficit for each summer (Fig. 8a C) to the preceding winter (1 November-1 March) (Fig. 8d) $(r=-0.4)$, suggests an inverse relationship between these variables. This empirical relationship is independently reinforced by observations at 186 reference sites across the arctic region [17], where there is strong correlation between January temperature and annual precipitation $(r=0.831)$, compared to July temperature and annual temperature $(r=0.135)$, and similarly January temperature with annual temperature $(r=0.986)$.

This linkage is fortuitous since the most robust and highest resolution palaeo-temperature proxy data available are the winter $\delta^{18} \mathrm{O}$ ice core data (Fig. 5c). Using the relationship established between high-resolution oxygen isotope measurements and measured temperatures at coring sites $(0.67 \%$ o per ${ }^{\circ} \mathrm{C}$; [37]) and at coastal locations $\left(0.7 \%\right.$ o per ${ }^{\circ} \mathrm{C}$; [60]) it is possible to derive mean winter temperatures from the $\delta^{18} \mathrm{O}$ ice core data. These relations are assumed to be applicable for the Norse settlement period, therefore allowing the severity of past winters to be examined and the relative frequency of particularly cold or warm winters to be assessed.

To compare the contemporary climate with these palaeotemperature data, deviations from respective means have been 
considered; with cold winters seen to lead to soil moisture deficits that determine a requirement for irrigation, the historic frequency of such a requirement can be established. From the palaeo-climate $\delta^{18} \mathrm{O}$ data set, the derived winter temperature is considered for each of five 100-year periods from $A D$ 982 to AD 1482 (Fig. 9). To allow short-term variation to be examined a mean is calculated for each period and the frequency and magnitude of significant temperature deviations have been calculated (Table 3). For the contemporary data set, winter is taken as 1 November to 1 March each year which approximates to the proportion $(\sim 29 \%$; $[66])$ of the annual ice core record considered as winter. The mean is taken from the daily mean temperatures for all winter period for all years (AD 1980-2003) and deviations for each winter period (e.g. 1 November 1980-1 March 1981) calculated. This analysis discounts the effects of the data resolution and that the ice core record is dependent upon precipitation. The results show (Table 3) that while the contemporary Narsarsuaq data have a higher frequency of large deviations from the mean than the periods considered by the ice core data, the data covering the Norse settlement period still show frequent major deviation. Using a threshold based on the deviations seen in years with significant water deficits (Fig. $8 \mathrm{a}-\mathrm{C}$ ) of $\geq 2{ }^{\circ} \mathrm{C}$ than the long-term mean, it is evident that c. $11 \%$ of years at the time of the Norse settlement of Greenland experienced droughty conditions, with this proportion increasing to c. $16 \%$ into the 14 th Century. 


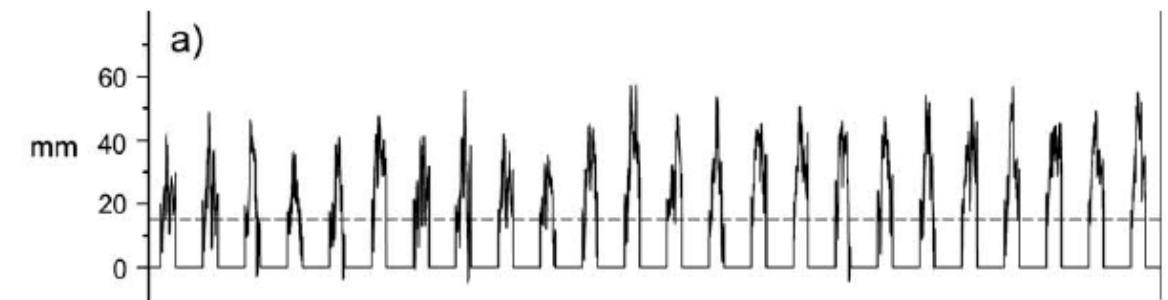

b)
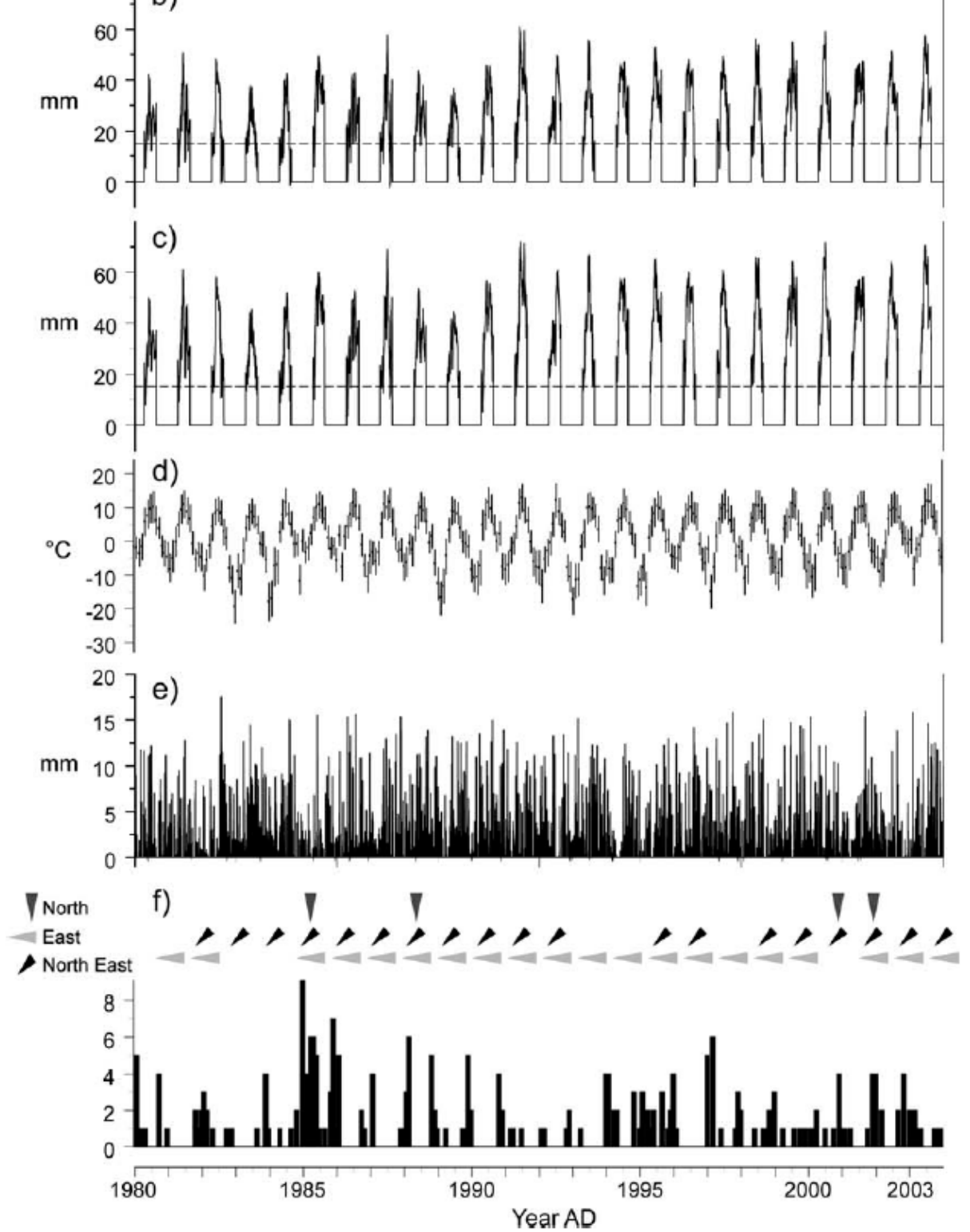

Fig. 8. Soil-plant-water modelling. Modelled soil-water deficits in the plant-root zone for the period 1980-2003 (a) Qassiarsuk (for $20 \mathrm{~cm}$ depth) (b) Tasersuaq (for $20 \mathrm{~cm}$ depth) (c) Tasersuaq (for $40 \mathrm{~cm}$ depth). Comparative agroclimatic data: (d) Mean monthly maximum, minimum and mean temperature of daily data (e) daily evapotranspiration (f) frequency and direction of chronic (i.e. $\geq 24$ h) dry katabatic gale events. 


\section{Conclusion}

In this paper the question of whether the Norse colonists of the Eastern Settlement of Greenland needed to develop irrigation techniques was posed. For the two sites considered, each strand of evidence examined has shown that there is a frequent requirement for irrigation, both at present and in the Norse settlement period. The empirical measurement of soil drainage parameters has successfully allowed modelling of the effect that inherent soil properties have on the need for irrigation relative to contemporary climate. It has been demonstrated that the demand for irrigation is particularly sensitive to the soil and site drainage parameters; these, in turn, relate to both the nature of the soil itself (organic content, particle size, stone content). Furthermore, any erosional losses from the home-field area during the Norse period would therefore have had two confounding effects, a reduction of the organic content of the soil, and a reduction in soil thickness, both increasing the need for irrigation.

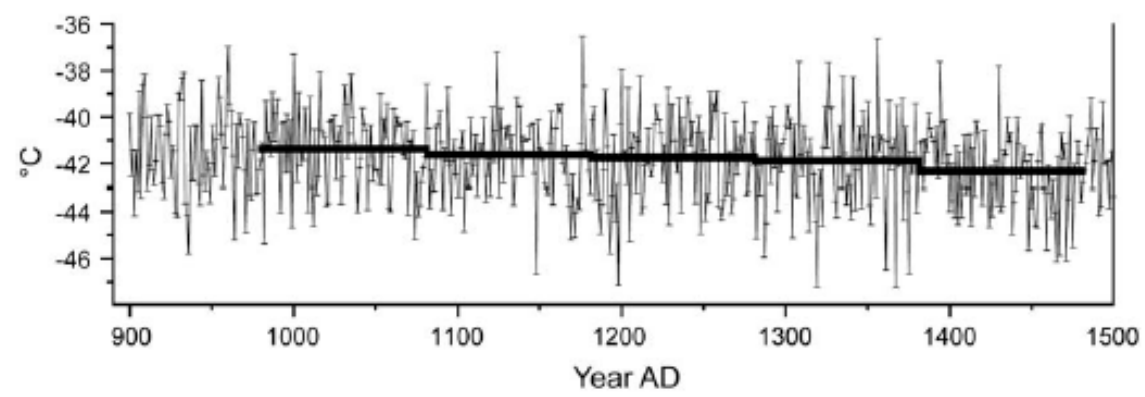

Fig. 9. Paleo-temperatures derived from the Dye 3 ice core $\delta^{18} 0$ winter temperature series showing 100-year mean values AD 982 to AD 1481.

From the results presented it is clear that the Greenlandic Norse settlers regularly faced one of two different soile planteclimate issues to maintain fodder production. In years with relatively warm winters, the increased growing season will have led to increased water demand from the grass crop, potentially demanding irrigation. Conversely, exceptionally cold winters appear to be linked to subsequent moisture deficits, and again a demand for irrigation despite the impact on crop productivity through reduction of the growing season length.

The overall home-field management practice seen in these two Greenlandic sites contrasts with that seen elsewhere. In 
Iceland, the 13th Century law book Grágás [15] codifies the construction and use irrigation channels, clearly indicating that irrigation on meadows and arable land was practiced at this time. Earlier early-Norse period references and examples of structures are unknown, however, the frequency of placename evidence (ÍSLEIF - digital archive of archaeological sites in Iceland, Institute of Archaeology, Reykjavík) suggests that irrigation was commonly seen on early Icelandic farms.

Whilst this may suggest a common practice with Greenland, grassland production in Iceland and the Faroe Islands has not previously been found to be limited by soil-water availability. The purpose of the practice can been seen to address different requirements in the Icelandic and Greenlandic contexts with the practice in Greenland critical to sustain production rather than enhance production. The assumption that practices adopted by the Greenlandic Norse colonists are similar to Icelandic practices, as understood from historical sources, has already been challenged [65]. Given that there is a set of feedback mechanisms involved in the management of the Greenlandic home-fields relative to short-term changes in the climatic conditions, transfer of knowledge from the Icelandic context may have raised a false analogy. Successful adoption or adaptation of irrigation practices as a regular home-field management practice may therefore be seen as the essential land management practice to maintain grass crops in the Norse Eastern Settlement of Greenland.

Table 3

Correspondence between paleo-climate and contemporary climate measurements

\begin{tabular}{|c|c|c|c|c|c|c|c|}
\hline \multirow[t]{3}{*}{ Period } & \multirow{3}{*}{$\begin{array}{l}\text { Mean winter } \\
\text { temperature } \\
\left({ }^{\circ} \mathrm{C}\right)\end{array}$} & \multicolumn{3}{|c|}{$\begin{array}{l}\text { Colder than mean } \\
\text { temperature by: }\end{array}$} & \multicolumn{3}{|c|}{$\begin{array}{l}\text { Warmer than mean } \\
\text { temperature by: }\end{array}$} \\
\hline & & $1-2{ }^{\circ} \mathrm{C}$ & $2-3{ }^{\circ} \mathrm{C}$ & $>3{ }^{\circ} \mathrm{C}$ & $1-2{ }^{\circ} \mathrm{C}$ & $2-3^{\circ} \mathrm{C}$ & $>3{ }^{\circ} \mathrm{C}$ \\
\hline & & $(\%)$ & $(\%)$ & $(\%)$ & $(\%)$ & $(\%)$ & $(\%)$ \\
\hline \multicolumn{8}{|l|}{ Narsarsuaq } \\
\hline AD $1980-2003$ & $-6.25^{\mathrm{a}}$ & 4 & 16 & 12 & 25 & 4 & 12 \\
\hline \multicolumn{8}{|l|}{ Dye 3 ice core } \\
\hline AD $1382-1481$ & $-42.35^{\mathrm{b}}$ & 9 & 6 & 6 & 18 & 8 & 2 \\
\hline AD $1282-1381$ & $-41.90^{b}$ & 5 & 11 & 7 & 8 & 11 & 5 \\
\hline $\mathrm{AD} 1182-1281$ & $-41.77^{\mathrm{b}}$ & 14 & 10 & 5 & 13 & 13 & 4 \\
\hline AD $1082-1181$ & $-41.65^{b}$ & 13 & 8 & 4 & 16 & 9 & 2 \\
\hline $\mathrm{AD} 982-1081$ & $-41.41^{\mathrm{b}}$ & 7 & 12 & 4 & 19 & 8 & 3 \\
\hline
\end{tabular}




\section{Acknowledgements}

The authors gratefully acknowledge the financial support of The Leverhulme Trust, Landscapes circum- landnám Programme. The Greenland National Museum and Archives provided invaluable assistance and kindly allowed site-access to the home-field areas. Two anonymous reviewers provided valuable comments on an earlier version of the manuscript. Bo Vinther from the Niels Bohr Institute, University of Copenhagen, kindly assisted with the collation of unpublished oxygen isotope data for the Crete and Dye 3 Greenlandic ice cores. The Danish Meteorological Institute, Copenhagen collated unpublished climatic data sets from Narsarsuaq weather station. Dr Tim Hess from Silsoe College, Cranfield University gave valuable advice on irrigation models. Dr Allan Lilly from the Macaulay Institute kindly advised on the field use of the Guelph Permeameter. From the University of Stirling, James Weir prepared the permeameter for Greenlandic field use and Bill Jamieson assisted the production of the maps and figures. 
References

[1] W.P. Adderley, I.A. Simpson, Early-Norse home-field productivity in the Faeroe Islands, Human Ecology 33 (2005) 711-736.

[2] R.G. Allen, L.S. Periera, D. Raes, M. Smith, Crop

Evapotranspiration - FAO Irrigation and Drainage Paper No. 56, FAO, Rome, 1996.

[3] T. Amorosi, P.C. Buckland, K.J. Edwards, I. Mainland, T.H.

McGovern, J.P. Sadler, P. Skidmore, They did not live by grass alone: the politics and paleoecology of animal fodder in the North Atlantic, Environmental Archaeology 1 (1998) 41-54.

[4] S.V. Arge, G. Sveinbjarnardóttir, K.J. Edwards, P.C. Buckland, Viking and medieval settlement in the Faroes: people, place and environment, Human Ecology 33 (2005) 597-620.

[5] J. Arneborg, Greenland irrigation systems on a West Nordic background. An overview of the evidence of irrigation systems in Norse Greenland c. 980-1450 AD, Ruralia V Supplementum 17. Water Management in the Medieval Rural Economy, Památky

Archaeologické, Prague, 2005, 137-145.

[6] L.K. Barlow, J.P. Sadler, A.E.J. Ogilvie, P.C. Buckland, T. Amorosi, J.H. Ingimundarson, P. Skidmore, A.J. Dugmore, T.H. McGovern, Interdisciplinary investigations of the end of the Norse Western Settlement in Greenland, The Holocene 7 (4) (1997) 489-499. [7] J. Berglund, The decline of the Norse settlements in Greenland, Arctic Anthropology 23 (1986) 109-135.

[8] D. Bruun, Arkæologiske Undersøgelser i Julianehaabs Distrikt, Meddelelser om Grønland 16 (3) (1895).

[9] P.C. Buckland, T. Amorosi, L.K. Barlow, A.J. Dugmore, P.A. Mayewski, T.H. McGovern, A.E.J. Ogilvie, J.P. Sadler, P. Skidmore, Bioarchaeological and climatological evidence for the fate of the Norse farmers in medieval Greenland, Antiquity 70 (1996) 88-96.

[10] S.M. Buckland, K. Thomson, J.G. Hodgson, J.P. Grime, Grassland invasions: effects of manipulations of climate and management, Journal of Applied Ecology 38 (2001) 301-309.

[11] J. Cappelen, B.V. Jørgensen, E.V. Laursen, L.S. Stannius, R.S. Thomsen, The observed climate of Greenland, 1958-99 with climatalogical standard normals 1961-1990 Technical Report 00-18, Danish Meteorological Institute, Copenhagen, 2001.

[12] M. Charles, C. Hoppé, A. Bogaard, G. Jones, J. Hodgson, Using weed functional attributes for the identification of irrigation regimes in Jordan, Journal of Archaeological Science 30 (2003) 1429-1441. [13] D. Dahl-Jensen, K. Mosegaard, G. Gundestrup, G.D. Clow, S.J. Johnson, A.W. Hansen, B. Balling, Past temperature directly from the Greenland ice-sheet, Science 282 (1998) 268-271. 
[14] W. Dansgaard, Stable isotopes in precipitation, Tellus 16 (1964) 436-468.

[15] A. Dennis, P. Foote, R. Perkins (Eds.), Laws of Early Iceland, Grágás: The Codex Regius of Grágás, vol. II, University of Manitoba Press, Winnipeg, 2000.

[16] D.E. Elrick, W.D. Reynolds, K.A. Tan, Hydraulic conductivity measurements in the unsaturated zone using improved well permeameter analysis, Groundwater Monitoring Review 1989 (1989) 184-193.

[17] B. Fréchette, A.P. Wolfe, G.H. Miller, P.J.H. Pierre J.H. Richard, A. de Vernal, Vegetation and climate of the last interglacial on Baffin Island, Arctic Canada, Palaeogeography, Palaeoclimatology, Palaeoecology, in press.

[18] B. Fredskild, Studies in the vegetational history of Greenland. Palaeobotanical investigations of some Holocence lake and bog deposits, Meddelelser om Grønland 198 (4) (1973).

[19] B. Fredskild, Paleobotanical investigations of some peat deposits of Norse age at Qagssiarssuk, South Greenland, Meddelelser om Grønland 204 (5) (1978).

[20] B. Fredskild, Agriculture in a marginal area: South Greenland AD 985-1985, in: H.H. Birks, H.J.B. Birks, P.E. Kaland, D. Moe (Eds.), The Cultural Landscape, Past, Present and Future, Cambridge, 1988, pp. 381-393.

[21] B. Fredskild, Agriculture in SW Greenland in the Norse Period (A.D. 982-c.1450), PACT 31 (5) (1992) 39-43.

[22] Geological Survey of Greenland, Geological Map 61 V.3 Syd, Narssarssuaq. 1:100,000 Compiled by J.H. Allaart, Geological Survey of Denmark and Greenland (GEUS), Copenhagen, 1973.

[23] A.J. Gijsman, S.S. Jagtap, J.W. Jones, Wading through the swamp of complete confusion: how to choose a method for estimating soil water retention parameters for crop models, European Journal of Agronomy 18 (2003) 77-106.

[24] O. Guldager, Brattahlíð reconsidered. Some thoughts on the social structure of medieval Norse Greenland, and the location of Brattahlíð, Archaeologica Islandica 2 (2002) 74-97.

[25] O. Guldager, S. Stummann Hansen, S. Gleie, Medieval farmsteads in Greenland, The Brattahlið Region 1999-2000, Danish Polar Center, Copenhagen, 2002.

[26] J.P. Grime, Plant Strategies and Vegetational Processes, J. Wiley, Chichester, 1979.

[27] B.U. Hansen, Using climate and vegetation studies in Southern Greenland to estimate the natural resources during the Norse period, Acta Borealia 1 (1991) 38-51. 
[28] B.U. Hansen, Monitoring natural vegetation in Southern Greenland using NOAA AVHRR and field measurements, Arctic 44 (1) (1991) 94-101.

[29] T. Hess, A microcomputer scheduling program for supplementary irrigation, Computers and Electronics in Agriculture 15 (1996) 233-243.

[30] T. Hess, P. Leeds-Harrison, C. Counsell, WaSim Technical Manual, Cranfield University, Oxford, HR Wallingford and Bedford, 2000.

[31] J.M. Hodgson, Soil Survey Field Handbook, in: Technical Monograph no. 5, Soil Survey of England and Wales, Harpenden, 1976.

[32] J.G. Hodgson, P. Halstead, P.J. Wilson, S. Davis, Functional interpretation of archaeobotanical data: making hay in the archaeological record, Vegetation History and Archaeobotany 8 (1999) 261-271.

[33] B.H. Jakobsen, Soil resources and soil erosion in the Norse settlement area of Østerbygden in Southern Greenland, Acta Borealia 1 (1991) 56-68.

[34] N.K. Jakobsen, Studies on soils and potential for soil erosion in the sheep farming area of South Greenland, Artic and Alpine Research 19 (1987) 498-507.

[35] S.J. Johnsen, H.B. Clausen, J. Jouzel, J. Schwander, A.E. Sveinbjörnsdóttir, J. White, Stable isotope records from Greenland deep ice cores: the climate signal and the role of diffusion, 156, NATO ASI Series, 1999, 89-107.

[36] S. Johnsen, D. Dahl-Jensen, W. Dansgaard, N. Gundestrup, Greenland palaeotemperatures derived from GRIP bore hole temperature and ice core isotope profiles, Tellus 47B (1995) 624629.

[37] S.J. Johnsen, W. Dansgaard, J.W. White, The origins of arctic precipitation under present and glacial conditions, Tellus 41B (1989) 452-468.

[38] J. Jouzel, R.B. Alley, K.M. Cuffey, W. Dansgaard, P. Grootes, G. Hoffmann, S.J. Johnsen, R.D. Koster, D. Peel, C.A. Shuman, M. Stievenard, M. Stuiver, J. White, Validity of temperature reconstruction from water isotopes in ice cores, Journal of Geophysical Research 102 (1997) 26471-26487.

[39] M.R. Kaplan, A.P. Wolfe, G.H. Miller, Holocene environmental variability in Southern Greenland inferred from lake sediments, Quaternary Review 58 (2002) 149-159.

[40] K.J. Krogh, Erik den Rødes Grønland, Nationalmuseet, Copenhagen, 1982. 
[41] A. Lilly, The determination of field-saturated conductivity is some Scottish soils using the Guelph permeameter, Soil Use and Management 16 (1994) 56-60.

[42] I. Mainland, Pastures lost? A dental microwear study of ovicaprine diet and management in Norse Greenland, Journal of Archaeological Science 33 (2006) 238-252.

[43] T.H. McGovern, Climate, correlation and causation in Norse Greenland, Arctic Anthropology 28 (1991) 77-100.

[44] T.H. McGovern, Management for extinction in Norse Greenland, in: C. Crumley (Ed.), Historical Ecology: Cultural Knowledge and Changing Landscapes, School of American Research Monograph, Santa Fe, 1994, pp. 127-154.

[45] T.H. McGovern, O. Vésteinsson, A. Fridriksson, M. Church, I. Lawson, I.A. Simpson, A. Einarsson, A. Dugmore, G. Cook, S.

Perdikaris, K. Edwards, A.M. Thomson, W.P. Adderley, A. Newton, G. Lucas, O. Aldred, Landscapes of Settlement in Northern Iceland: Historical Ecology of Human Impact and Climate Fluctuation on the Millennial Scale. American Anthropologist, submitted for publication. [46] J. Meldgaard, Tjodhildes Kirke; den forste fundberetning, Grønland 1982 (1982) 151-162.

[47] D.W. Nelson, L.E. Sommers, Total carbon, organic carbon and organic matter, in: A.L. Page, R.H. Miller, D.R. Keeney (Eds.), Methods of Soil Analysis, Part 2, Chemical and Microbiological Properties, American Society of Agronomy, Madison, Wisconsin, 1982, pp. 539-579.

[48] P. Nørlund, M. Stenberger, Brattahlid, Meddelelser om Grønland 88 (1) (1934).

[49] A.E.J. Oglivie, L.K. Barlow, A.E. Jennings, North Atlantic climate C $A D$ 1000. Millenial reflections on the Viking discoveries of Iceland, Greenland and North America, Weather 55 (2000) 34-45.

[50] A.E.J. Ogilvie, Climatic changes in Iceland AD c865 to 1598, Acta Archaeologica 61 (1991) 233-251.

[51] J.E. Olson, E.G. Bourne (Eds.), Papal Letters Concerning the Bishophric of Gardar in Greenland during the Fifteenth Century, The Northmen, Columbus and Cabot, 985-1503: The Voyages of the Northmen; The Voyages of Columbus and of John Cabot, Charles Scribner's Sons, New York, 1906, pp. 70-74.

[52] W.J. Rawls, D.L. Brakensiek, Estimating soil water retention from soil properties, Journal of the Irrigation and Drainage Division ASCE 108 (1982) 166-171.

[53] W.D. Reynolds, D.E. Elrick, In situ measurement of fieldsaturated hydraulic conductivity, sorptivity, and the a-parameter using the Guelph permeameter, Soil Science 140 (1985) 292-302. 
[54] W.D. Reynolds, S.R. Vieira, G.C. Topp, An assessment of the single-head analysis for the constant head well permeameter, Canadian Journal of Soil Science 72 (1992) 489-501.

[55] A. Roussell, Farms and churches of the mediaeval Norse settlements of Greenland, Meddelelser om Grønland 89 (1) (1941). [56] G.K. Rutherford, Soils of some Norse settlements in southwestern Greenland, Arctic 48 (1995) 324-328.

[57] I.A. Simpson, W.P. Adderley, G. Guðmundsson, M. Hallsdóttir, M.A. Sigurgeirsson, M. Snæsdóttir, Soil limitations to agrarian land production in premodern Iceland, Human Ecology 30 (2002) 423-443. [58] Soil Conservation Service, Urban Hydrology for Small Watersheds Technical Release 55, USDA, Washington DC, 1986. [59] Soilmoisture Equipment, Guelph Permeameter 2800KI Operating Instructions, Soilmoisture Equipment Corp., Santa Barbara, 1991. [60] J.P. Steffensen, Microparticles in snow from the South Greenland ice sheet, Tellus 37B (1985) 286-295.

[61] D.A. Stephenson, A.H. Fleming, D.M. Mickelson, Glacial deposits, in: W. Back, J.S. Rosenhein, P.R. Seaber (Eds.), Hydrogeology, The Geology of North America, vol. O2, Geology Society of America, Boulder, Colorado, 1988, pp. 301-314.

[62] T.E. Sveistrup, T.K. Haraldsen, R. Langohr, V. Marcelino, J. Kværner, Impact of land use and seasonal freezing on morphological and physical properties of silty Norwegian soils, Soil and Tillage Research 81 (2005) 39-56.

[63] G. Thorvaldsson, P.T. Haahr, K. Høegh, Growth, development and nutritional value of grass species cultivated in Greenland, Iceland and the Faroe Islands, 1996-1998. Rala Report 206, Agricultural Research Institute, Reykjavík, Iceland, 2000.

[64] C.D. Trombold, I. Israde-Alcantara, Paleoenvironment and plant cultivation on terraces at La Quemada, Zacatecas, Mexico: the pollen, phytolith and diatom evidence, Journal of Archaeological Science 32 (2005) 341e-353.

[65] O. Vésteinsson, T.H. McGovern, C. Keller, Enduring impacts: social and environmental aspects of Viking age settlement in Iceland and Greenland, Archaeologica Islandica 2 (2002) 98-136.

[66] B.M. Vinther, S.J. Johnsen, K.K. Andersen, H.B. Clausen, A.W. Hansen, NAO signal recorded in the stable isotopes of Greenland ice cores, Geophysical Research Letters 30 (2003) 1387.

[67] P.A. Wookey, A.N. Parsons, J.M. Welker, J.A. Potter, T.V.

Callaghan, J.A. Lee, M.C. Press, Comparative responses of phenology and reproductive development to simulated environmental change in sub-arctic and high arctic plants, Oikos 67 (1993) 490-502. 